\title{
Volume Information
}

\section{Volume 219, 2011}

\section{Table of Contents}

\section{Topical Issue: Multi-Digit Number Processing}

\section{Editorial}

1 Multi-Digit Number Processing

Hans-Christoph Nuerk, Klaus Willmes, and Martin H. Fischer

\section{Review Article}

3 Extending the Mental Number Line: A Review of Multi-Digit Number Processing Hans-Christoph Nuerk, Korbinian Moeller, Elise Klein, Klaus Willmes, and Martin H. Fischer

\section{Original Articles}

23 Sequential Processing of Two-Digit Numbers: Evidence of Decomposition From a Perceptual Number Matching Task Javier García-Orza and Jesús Damas

30 Digit Repetition Effect in Two-Digit Number Comparison

Simone Gazzellini and Alessandro Laudanna

37 The Processing of Two-Digit Numbers Depends on Task Instructions

Bert Reynvoet, Karolien Notebaert, and Eva Van den Bussche

42 Attentional Strategies in Place-Value Integration: A Longitudinal Study on Two-Digit Number Comparison Anne Mann, Korbinian Moeller, Silvia Pixner, Liane Kaufmann, and Hans-Christoph Nuerk

50 Operational Momentum in Numerosity Production Judgments of Multi-Digit Number Problems Oliver Lindemann and Michael D. Tira

\section{Opinion}

58 Psychophysics of Numerical Representation: A Unified Approach to Single- and Multi-Digit Magnitude Estimation Christopher J. Young and John E. Opfer
64 Psychophysics of Numerical Representation: Why Seemingly Logarithmic Representations May Rather Be Multi-Linear Korbinian Moeller and Hans-Christoph Nuerk

\section{Horizons}

71 Multi-Digit Number Processing

\section{Topical Issue: Prospective Memory}

\section{Editorial}

75 Prospective Memory: Beyond the Cost Debate Rebekah E. Smith

\section{Original Articles}

77 Varying the Complexity of the Prospective Memory Decision Process in an Air Traffic Control Simulation

Shayne Loft, Ben Pearcy, and Roger W. Remington

85 An Investigation of Prospective and Retrospective Coding in Capuchin Monkeys and Rhesus Monkeys Emily D. Klein, Theodore A. Evans, and Michael J. Beran

92 Time-Based Prospective Memory in Schoolchildren: The Role of Self-Initiation and Strategic Time Monitoring

Babett Voigt, Ingo Aberle, Judith Schönfeld, and Matthias Kliegel

100 Examining Collaborative Dialogue Among Couples: A Window Into Prospective Memory Processes Jennifer A. Margrett, Celinda Reese-Melancon, and Peter G. Rendell

108 Prospective Memory, Personality, and Working Memory: A Formal Modeling Approach Rebekah E. Smith, Deborah Persyn, and Patrick Butler

117 Analyzing Response Time Distributions: Methodological and Theoretical Suggestions for Prospective Memory Researchers Gene A. Brewer

\section{Horizons}

125 Recent and Upcoming Events for Prospective Memory Researchers Rebekah E. Smith 


\section{Topical Issue: Torture}

\section{Editorial}

129 Torture: Psychological Approaches to a Major Humanitarian Issue Roland Weierstall, Thomas Elbert, and Andreas Maercker

\section{Review Article}

133 The Trauma of Torture and the Rehabilitation of Torture Survivors Lilla Hárdi and Adrienn Kroó

\section{Original Articles}

143 Screening for Torture: A Narrative Checklist Comparing Legal Definitions in a Torture Treatment Clinic Andrew Rasmussen, Mia Crager, Eva Keatley, Allen S. Keller, and Barry Rosenfeld

150 Are the American Psychological Association's Detainee Interrogation Policies Ethical and Effective? Key Claims, Documents, and Results Kenneth S. Pope

159 On the Imposition of Torture, an Extreme Stressor State, to Extract Information From Memory: A Baleful Consequence of Folk Cognitive Neurobiology Shane O'Mara

167 The Tortured Brain: Imaging Neural Representations of Traumatic Stress Experiences Using RSVP With Affective Pictorial Stimuli Thomas Elbert, Maggie Schauer, Martina Ruf, Roland Weierstall, Frank Neuner, Brigitte Rockstroh, and Markus Junghöfer

175 Dehumanized Perception: A Psychological Means to Facilitate Atrocities, Torture, and Genocide? Lasana T. Harris and Susan T. Fiske

\section{Research Spotlights}

182 Torture and Atrocity Sequelae in Methodologically Sophisticated Studies Andreas Maercker and Simon Forstmeier

184 Torture as Negative Excessive Behavior of Revenge and Punishment Andreas Maercker and Tobias Glück

\section{Opinion}

187 Mental Health Interventions for Survivors of Torture: Current Status and Future Directions Karni Ginzburg and Yuval Neria

190 US Torture and National Security: The Imperative of Accountability Vincent Iacopino
193 Torture 101

Martha K. Huggins

\section{Topical Issue: Consumer Behavior \& Economic Decisions}

Editorial

195 Economic and Psychological Determinants of Consumer Behavior

Erich Kirchler and Erik Hoelzl

\section{Review Article}

198 The Division of Household Tasks and Household Financial Management Gerrit Antonides

\section{Original Articles}

209 The Accuracy of Consumers' Perception of Future Inflationary Price Changes Fabian Christandl and Tommy Gärling

217 The Impact of Transaction Utility on Consumer Decisions: The Role of Loss Aversion and Acquisition Utility Stephan Muehlbacher, Erich Kirchler, and Angelika Kunz

224 Mortality Salience and Worldview Affirmation Strengthen Support for Foreign Products Daniel Sullivan, Eva Jonas, and Barbara Jodlbauer

231 When Imagery Influences Spending Decisions: The Role of Ownership Simulations Bernadette Kamleitner

238 The Influence of Anticipated Emotions on Consumer Decisions: Examining the Role of Product Type and Belief in Adaptation Maria Pollai, Erik Hoelzl, Luise Hahn, and Alexandra Hahn

246 Why Do People Save? The Influence of Financial Satisfaction and Income on Saving Eva Traut-Mattausch and Eva Jonas

\section{Horizons}

253 Consumer Decisions as a Central Research Topic in Economic Psychology Erik Hoelzl and Erich Kirchler

\section{Calls for Papers}

72 "Evolutionary Psychology: Beyond Adaptationist Just-So Stories?": A Topical Issue of the Zeitschrift für Psychologie / Journal of Psychology Guest Editor: Werner Greve

73 "Self-Control and Self-Regulation in Social Contexts": A Topical Issue of the Zeitschrift für Psychologie / Journal of Psychology Guest Editors: Kai Sassenberg and Jennifer Fehr 
127 "Sex and Gender Differences Revisited - New Perspectives and New Findings": A Topical Issue of the Zeitschrift für Psychologie / Journal of Psychology Guest Editors: Markus Hausmann and Barbara Schober

128 "Followercentric Approaches to Leadership": A Topical Issue of the Zeitschrift für Psychologie / Journal of Psychology Guest Editors: Michelle C. Bligh and Jeffrey C. Kohles
255 "Task Switching": A Topical Issue of the Zeitschrift für Psychologie Guest Editors: Iring Koch and Marcel Brass

\section{Volume Information, Volume 219, 2011}

256 Table of Contents / Author Index / Keyword Index / Reviewers

\section{Author Index}

\begin{tabular}{|c|c|c|}
\hline Aberle, I, & 92 & Jodlbauer, B. \\
\hline Antonides, G. & 198 & Jonas, E. \\
\hline Beran, M. J. & 85 & Jungnoier, IVI. \\
\hline Brewer, G. A. & 117 & Kamleitner, B. \\
\hline Butler, P. & 108 & Kaufmann, L. \\
\hline Christandl, F. & 209 & $\begin{array}{l}\text { Keatley, E. } \\
\text { Keller, A. S. }\end{array}$ \\
\hline Crager, M. & 143 & Kirchler, E. \\
\hline Damas, J. & 23 & $\begin{array}{l}\text { Klein, E. } \\
\text { Klein, E. D. }\end{array}$ \\
\hline Elbert, T. & 129,167 & Kliegel, M. \\
\hline Evans, T. A. & 85 & $\begin{array}{l}\text { Kroó, A. } \\
\text { Kunz, A. }\end{array}$ \\
\hline Fischer, M. H. & 1,3 & \\
\hline Fiske, S. T. & 175 & Laudanna, A. \\
\hline Forstmeier, S. & 182 & $\begin{array}{l}\text { Lindemann, O. } \\
\text { Loft, S. }\end{array}$ \\
\hline García-Orza, J. & 23 & \\
\hline Gärling, T. & 209 & Maercker, A. \\
\hline Gazzellini, S. & 30 & Mann, A. \\
\hline Ginzburg, K. & 187 & Margrett, J. A. \\
\hline Glück, T. & 184 & $\begin{array}{l}\text { Moeller, K. } \\
\text { Muehlbacher, S. }\end{array}$ \\
\hline Hahn, A. & 238 & \\
\hline Hahn, L. & 238 & Neria, Y. \\
\hline Hárdi, L. & 133 & Neuner, F. \\
\hline Harris, L. T. & 175 & Notebaert, K. \\
\hline Hoelzl, E. & $195,238,253$ & Nuerk, H.-C. \\
\hline Huggins, M. K. & 193 & O’Mara, S. \\
\hline Iacopino, $\mathrm{V}$. & 190 & Opfer, J. E. \\
\hline
\end{tabular}

224

224,246

167

231

42

143

143

$195,217,253$

3

85

92

133

217

30

50

77

129, 182, 184

42

100

$3,42,64$

217

187

167

37

$1,3,42,64$

159
Pearcy, B.

Persyn, D.

Pixner, S.

Pollai, M.

Pope, K. S.

Rasmussen, A.

Reese-Melancon, C.

Remington, R. W.

Rendell, P. G.

Reynvoet, B.

Rockstroh, B.

Rosenfeld, B.

Ruf, M.

Schauer, M.

Schönfeld, J.

Smith, R. E.

Sullivan, D.

Tira, M. D.

Traut-Mattausch, E.

Van den Bussche, E.

Voigt, B.

Weierstall, R.

Willmes, K.

Young, C. J.
129, 167

1,3

77

108

42

238

150

143

100

77

100

37

167

143

167

167

92

$75,108,125$

224

50

246

37

92

58 


\section{Keyword Index}

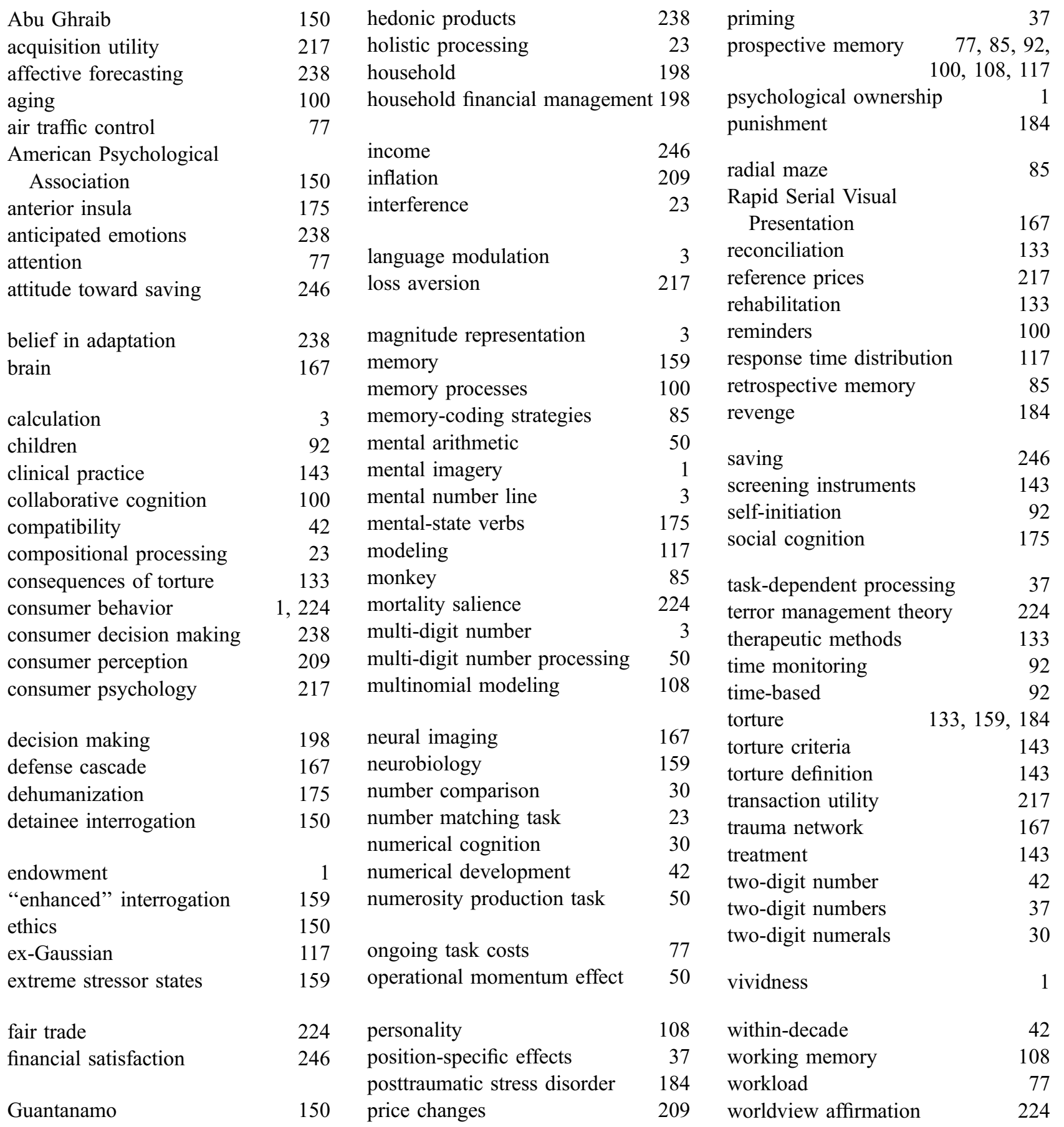




\section{Reviewers 2011}

The Zeitschrift für Psychologie / Journal of Psychology expresses its thanks to the following colleagues who contributed to the peer review of manuscripts this year. They reviewed the incoming manuscripts very conscientiously and provided constructive suggestions to many of our authors. Furthermore, in most cases they reviewed quickly, which is a fundamental prerequisite for a rapid manuscript management. The editors of the Zeitschrift für Psychologie / Journal of Psychology are greatly indebted to all of them.

Eduard Brandstätter

Gene Brewer

Fabian Christandl

Bert De Smedt

Key Dismukes

John Dunlosky

Thomas Elbert

Jerome Endrass

Georg Felser

Martin H. Fischer

Peter Fischer

Giovanni Galfano

Dana Ganor-Stern

Luisa Girelli

Silke Goebel

Jacques Grégoire

Tobias Greitemeyer

Lilla Hardi

Lasana Harris

Erik Hoelzl

Martha Huggins
Eric Igou

Kimberly Kerns

Erich Kirchler

André Knops

Martin Kocher

Stephen Lea

Leonard Lee

Boris Maciejovsky

Anna Maedl

Andreas Maercker

Thad Meeks

Harold Miesen

Korbinian Moeller

Morten Moshagen

Hans-Christoph Nuerk

Ellen Nyhus

Thomas Oberlechner

Ann Pearman

Manuel Perea

Michal Pinhas

Julia Pitters
Ken Pope

Anu Raijas

Andrew Rasmussen

Rob Ranyard

Martina Ruf

Elena Rusconi

Inga Schalinski

Maggie Schauer

Rebekah E. Smith

Hakon Stenmark

Tadeusz Tyszka

Jean-Philippe van Dijck

Andreas Voss

Roland Weierstall

Robert West

Klaus Willmes

Mark Wooden

Tomasz Zaleskiewicz

Thomas Zentall 